\title{
In vivo monitoring of plant small GTPase activation using a Förster resonance energy transfer biosensor
}

\author{
Hann Ling Wong ${ }^{1,2+}$, Akira Akamatsu ${ }^{1,3+}$, Qiong Wang ${ }^{4,5+}$, Masayuki Higuchi ${ }^{1}$, Tomonori Matsuda ${ }^{1}$, Jun Okuda ${ }^{1}$, \\ Ken-ichi Kosami ${ }^{4}$, Noriko Inada ${ }^{6}$, Tsutomu Kawasaki 1,7, Takako Kaneko-Kawano ${ }^{8}$, Shingo Nagawa9, ${ }^{9}$, Li Tan9, \\ Yoji Kawano ${ }^{1,4,11^{*}}$ (D) and Ko Shimamoto ${ }^{1 \wedge}$
}

\begin{abstract}
Background: Small GTPases act as molecular switches that regulate various plant responses such as disease resistance, pollen tube growth, root hair development, cell wall patterning and hormone responses. Thus, to monitor their activation status within plant cells is believed to be the key step in understanding their roles.

Results: We have established a plant version of a Förster resonance energy transfer (FRET) probe called Ras and interacting protein chimeric unit (Raichu) that can successfully monitor activation of the rice small GTPase OsRac1 during various defence responses in cells. Here, we describe the protocol for visualizing spatiotemporal activity of plant Rac/ ROP GTPase in living plant cells, transfection of rice protoplasts with Raichu-OsRac1 and acquisition of FRET images.

Conclusions: Our protocol should be adaptable for monitoring activation for other plant small GTPases and proteinprotein interactions for other FRET sensors in various plant cells.
\end{abstract}

Keywords: Small GTPase, FRET sensor, Bioimaging, Plant immunity

\section{Background}

Scientists have wanted for many years to observe events in living cells at the molecular level, and fluorescent proteins offer powerful tools for doing so. Förster Resonance Energy Transfer (FRET) is a physical phenomenon that can be sensitive to changes in molecular conformation and association typically in the $1-10 \mathrm{~nm}$ range $[1,2]$. In FRET applications, a pair of donor and acceptor fluorescent proteins is used to monitor a variety of biological events including protein-protein interactions, protein kinase activities, post-translational modifications and the dynamics of second messengers [3-6]. When the

\footnotetext{
*Correspondence: yoji.kawano@sibs.ac.cn

${ }^{\dagger}$ Hann Ling Wong, Akira Akamatsu and Qiong Wang contributed equally to this work

${ }^{\wedge}$ Deceased

${ }^{4}$ Present Address: Signal Transduction and Immunity Group, CAS Center for Excellence in Molecular Plant Sciences, Shanghai Center for Plant Stress Biology, Chinese Academy of Sciences, No. 3888 Chenhua Road, Shanghai 201602, China

Full list of author information is available at the end of the article
}

emission spectrum of a donor fluorescent protein overlaps with the absorption spectrum of an acceptor fluorescent protein, and the distance between the two proteins is less than $10 \mathrm{~nm}$, non-radiative transfer of energy occurs from the donor to the acceptor.

Small GTPases exhibit both GDP/GTP-binding activity and GTPase activity, and work as molecular switches by cycling between GDP-bound inactive and GTP-bound active forms. Rac/ROP family small GTPases are master regulators, controlling various signalling systems in plants such as those governing pollen tube growth, root hair development, auxin signaling, and disease resistance [7-10]. Therefore, monitoring the activation state of a Rac/ROP GTPase within living cells is critical to further understanding its functions. Until the 1990s, activation states of small GTPases were measured in vivo by labelling cells with inorganic $\left[{ }^{32} \mathrm{P}\right]$ phosphate, followed by immunoprecipitation of small GTPases and thin-layer chromatography to obtain quantitative data for their associated GDP and GTP levels. However, this method

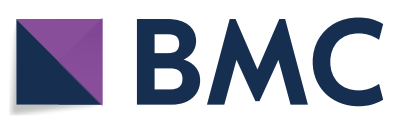

(c) The Author(s) 2018. This article is distributed under the terms of the Creative Commons Attribution 4.0 International License (http://creativecommons.org/licenses/by/4.0/), which permits unrestricted use, distribution, and reproduction in any medium, provided you give appropriate credit to the original author(s) and the source, provide a link to the Creative Commons license, and indicate if changes were made. The Creative Commons Public Domain Dedication waiver (http://creativecommons.org/ publicdomain/zero/1.0/) applies to the data made available in this article, unless otherwise stated. 
required not only large amounts of radioisotope but also a time-consuming procedure. Currently, two alternative non-radioactive techniques are available for monitoring the in vivo activation of Rac/ROP: a PAK CRIB pulldown assay, and FRET sensors [5, 11-13]. These methods exploit the selective interaction between the Cdc42/Rac interactive binding (CRIB) domain of the Rac-effector PAK1 (PAK CRIB) and plant and animal Rac GTPases. PAK CRIB shows a high affinity only for the active GTPbound form of Rac, and not for the inactive GDP-bound form $[11,13]$. PAK CRIB binding suppresses the intrinsic GTPase activity of Rac, and this function provides a useful tool for isolating active GTP-bound forms of Rac/ROP from crude cell lysates and for monitoring the activation state of Rac/ROP in living cells. Currently, kits using GST-tagged PAK CRIB for a PAK CRIB pull-down assay are available from several manufacturers (e.g., Cytoskeleton). This is a widely used method for the semi-quantitative measurement of Rac/ROP activity from plants to animals $[11,12,14]$. However, the PAK CRIB pull-down assay only provides a snapshot, and cannot detect the spatial and temporal dynamics of intracellular signaling in living cells. To solve this problem, FRET biosensors for small GTPases have been developed.

FRET biosensors that have been developed to visualize small GTPase activity in living cells can be classified into two types: intramolecular (or unimolecular) and intermolecular (or bimolecular) biosensors. Both types exploit the ability of two different proteins to interact with each other when one of them is activated. Intramolecular biosensors have both donor and acceptor fluorescent proteins in one molecule, whereas a donor and an acceptor fluorescent protein are expressed separately in intermolecular biosensors. The first report on in vivo monitoring of a small GTPase involved intermolecular biosensors, namely the combination of animal cultured cells expressing green fluorescent protein (GFP)-Rac as the donor and microinjection of PAK CRIB labeled with Alexa 546 dye as the acceptor, which binds selectively to the GTP-active form of Rac [15]. In plants, an intermolecular FRET biosensor was built to analyze ROP2 activity. With this sensor, which used a downstream effector protein of the small GTPase ROP2, CFP-RIC4 (donor), and YFP-ROP2 (acceptor), it was shown that ROP2 is preferentially activated in lobe-forming regions of the cell cortex [16].

However, there are several disadvantages in systems involving intermolecular biosensors. For example, to obtain reliable data from FRET analyses, we have to control the expression levels of donors and acceptors [17]. The expression level of the acceptor should be higher than that of the donor; moreover, a high proportion of activated donors must associate with acceptors to obtain sufficiently high signal/noise ratios to prevent FRET signals from being buried under noise. In plants, particle bombardment of plasmids into leaf epidermal pavement cells of Arabidopsis is often carried out for FRET analyses, but it is technically difficult to obtain appropriate levels of expression of donors and acceptors in Arabidopsis using intermolecular biosensors. Moreover, excessive expression of acceptors can cause abnormal activation or inhibition of downstream molecules.

To overcome these disadvantages, Matsuda and his colleagues have developed excellent intramolecular FRET biosensors for small GTPases in animal cells, collectively naming them Raichu (Ras superfamily and interacting protein chimeric unit). Raichu was initially developed to study activation of the small GTPases Ras and Rap1 following growth factor stimulation in animal cells $[5,18]$. The original Raichu contains a donor (cyan-emitting fluorescent protein; CFP), an acceptor (yellow-emitting fluorescent protein; YFP), and the Ras-binding domain of Raf (RBD), which is a downstream effector and binds specifically to active Ras. Therefore, the molar ratio of the individual component proteins is the same irrespective of expression level. Accordingly, this intramolecular FRET biosensor eliminates the problem of variability in the expression levels of donor and acceptor fluorescent proteins and is an ideal sensor for monitoring the activation states of small GTPases.

Subsequently, Raichu and its variants have become well-established tools for visualizing the activation of various small GTPases, including Rac1, Cdc42, RhoA, Ral, TC10 and Rab5 in animals [9, 19]. Raichu-Rac1, one of the variants of Raichu, is composed of the yellowemitting fluorescent protein Venus, the small GTPase human Rac1, a linker, the CRIB domain of PAK, CFP, and the $\mathrm{C}$-terminal polybasic region and post-translational modification site of KiRas at the $\mathrm{C}$ terminus [5]. In the GDP-bound inactive form of Raichu-Rac1, PAK CRIB does not bind to Rac1 and the donor CFP remains remote from the acceptor Venus, resulting in a low FRET efficiency (Fig. 1). Upon activation of endogenous GEF by extracellular signals, GEF facilitates the release of GDP from Rac1, thereby converting Rac1 into a nucleotidefree form. Owing to the high intracellular concentration of GTP, Rac1 is then converted to the active form after autonomously binding to GTP. Intramolecular binding of active GTP-Rac1 to PAK CRIB brings CFP closer to Venus, thus enabling FRET from CFP to Venus to occur. The resulting Venus fluorescence provides an estimate of the activation state of Rac1 in vivo, with low and high ratios of Venus/CFP fluorescence corresponding to low and high levels of Rac1 activation, respectively.

We have previously revealed that the small GTPase OsRac1 is an important regulator controlling rice 


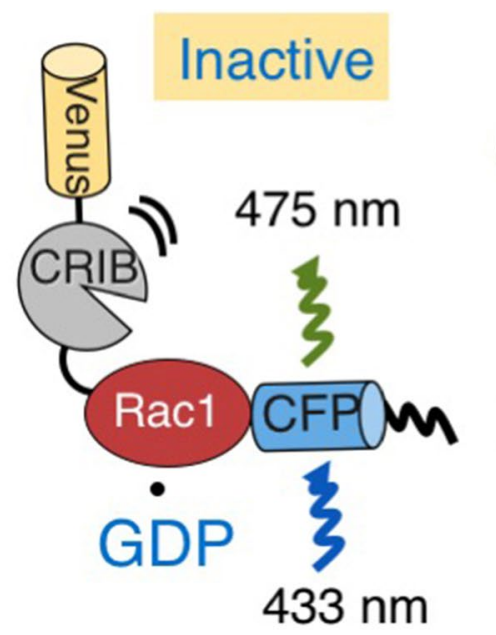

Rac1-CRIB interaction: Weak FRET: LOW Venus/CFP ratio: Low

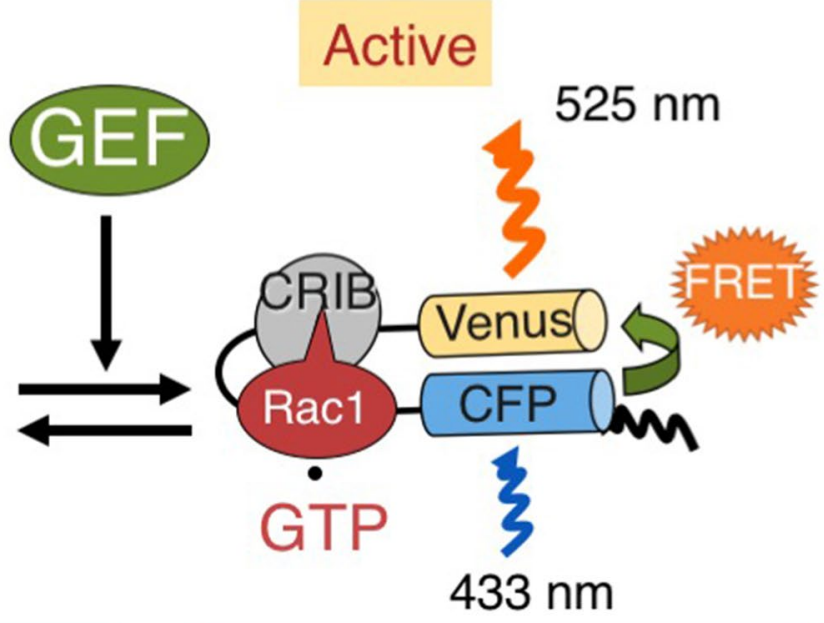

Rac1-CRIB interaction: Strong

FRET: High

Venus/CFP ratio: High
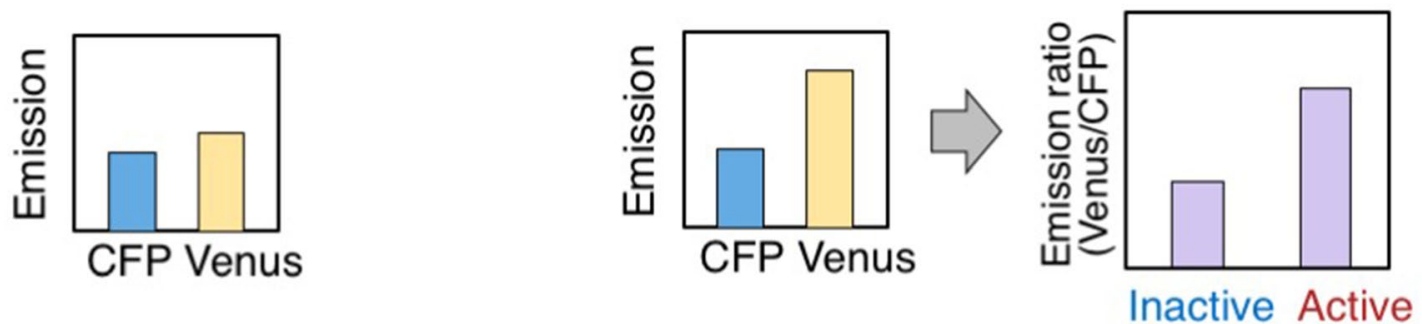

Fig. 1 Mechanism of Raichu-OsRac1 FRET sensor. Raichu-Rac1 consists of the fluorescent protein Venus (yellow), the CRIB domain of PAK (grey), the small GTPase Rac1 (red) and the fluorescent protein CFP (cyan). When OsRac1 is bound to GDP, the intramolecular association between the CRIB domain of PAK is weak, and fluorescence of $475 \mathrm{~nm}$ thus emanates from CFP upon excitation at $433 \mathrm{~nm}$. When OsRac1 is bound to GTP, intramolecular interaction between the PAK CRIB domain and OsRac1 brings CFP and Venus into close proximity, causing FRET and fluorescence of Venus at $525 \mathrm{~nm}$

immunity [9, 10, 20], and monitoring its activation within living cells is therefore the next key step in further elucidating how plants trigger immunity. To monitor activation states of OsRac1, we have developed a plant version of the Raichu-Rac1 system by combining the modification of human Raichu-Rac1 and a rice protoplast transfection system. Protoplasts do not possess a cell wall, and this enables direct live imaging of events both within the cell and at the cell surface, simultaneously and with no time delay in the response. Rice protoplasts also display a high growth rate and a high transfection rate, and we can control the expression levels of FRET sensors in plant cells without difficulty. Our work has pioneered the monitoring of spatiotemporal activities of plant small GTPases in living cells, which had been impossible by conventional biochemical methods [13]. We have observed the resistance $(\mathrm{R})$ protein Pit, an immune receptor that activates OsRac1 at the plasma membrane [13, 21], and reported that OsRac1 is activated within 3 min after treatment with a fungal cell wall component, chitin [22], which is a microbe-associated molecular pattern (MAMP) that triggers plant immunity.

\section{Results and discussion \\ Materials}

- 2,4-Dichlorophenoxyacetic acid (2,4-D) $\left(\mathrm{C}_{8} \mathrm{H}_{6} \mathrm{Cl}_{2} \mathrm{O}\right)$ (Sigma, Cat. no. D7299).

- Agarose, low gelling temperature (Sigma, Cat. no. A9414).

- Ammonium sulphate $\left(\left(\mathrm{NH}_{4}\right)_{2} \mathrm{SO}_{4}\right)$ (Sigma, Cat. no. A3920). 
- Boric acid $\left(\mathrm{H}_{3} \mathrm{BO}_{3}\right)$ (Sigma, Cat. no. B6768).

- Calcium chloride dihydrate $\left(\mathrm{CaCl}_{2} \cdot 2 \mathrm{H}_{2} \mathrm{O}\right)$ (Sigma, Cat. no. C5080).

- Cellulase RS (Yakult, Cat. no. C8260).

- Chitin $\left(N, N^{\prime}, N^{\prime \prime}, N^{\prime \prime \prime}, N^{\prime \prime \prime \prime}, N^{\prime \prime \prime \prime \prime}\right.$ hexaacetylchitohexaose) (Carbosynth., Cat. no. OH07433).

- Copper(II) sulphate pentahydrate $\left(\mathrm{CuSO}_{4} \cdot 5 \mathrm{H}_{2} \mathrm{O}\right)$ (Sigma, Cat. no. C8027).

- D-mannitol $\left(\mathrm{C}_{6} \mathrm{H}_{14} \mathrm{O}\right)$ (Sigma, Cat. no. M1902).

- Deionized, distilled water $\left(\mathrm{ddH}_{2} \mathrm{O}\right)$.

- Ethylenediaminetetraacetic acid disodium salt dihydrate ( $\mathrm{Na}_{2}$ EDTA) (Sigma, Cat. no. E5134).

- Glycine $\left(\mathrm{C}_{2} \mathrm{H}_{5} \mathrm{NO}\right)$ (Sigma, Cat. no. G7126)

- Iron(II) sulphate heptahydrate $\left(\mathrm{FeSO}_{4} \cdot 7 \mathrm{H}_{2} \mathrm{O}\right)$ (Sigma, Cat. no. F8633).

- Macerozyme R10 (Yakult, Cat. no. C1003).

- Magnesium chloride $\left(\mathrm{MgCl}_{2}\right)$ (Sigma, Cat. no. M8266).

- Magnesium sulphate heptahydrate $\left(\mathrm{MgSO}_{4} \cdot 7 \mathrm{H}_{2} \mathrm{O}\right)$ (Sigma, Cat. no. 63138).

- Manganese(II) sulphate tetrahydrate $\left(\mathrm{MnSO}_{4} \cdot 4 \mathrm{H}_{2} \mathrm{O}\right)$ (Alfa Aesar, Cat. no. B22081)! CAUTION It is toxic and dangerous for the environment. Handle it with care, and wear gloves and eye protection.

- MES monohydrate $\left(\mathrm{C}_{6} \mathrm{H}_{13} \mathrm{NO}_{4} \mathrm{~S} \cdot \mathrm{H}_{2} \mathrm{O}\right)$ (Fluka, Cat. no. 69889).

- Murashige and Skoog (MS) Vitamin (Sigma, Cat. no. M3900).

- Myo-inositol $\left(\mathrm{C}_{6} \mathrm{H}_{12} \mathrm{O}_{6}\right)$ (Sigma, Cat. no. I7508).

- Nicotinic acid $\left(\mathrm{C}_{6} \mathrm{H}_{5} \mathrm{NO}_{2}\right)$ (Sigma, Cat. no. N0761).

- Polyethylene glycol (PEG 4000) (Sigma, Cat. no. 81240).

- Potassium chloride (KCl) (Sigma, Cat. no. P9541).

- Potassium nitrate $\left(\mathrm{KNO}_{3}\right)$ (Sigma, Cat. no. P6083).

- Pyridoxine hydrochloride $\left(\mathrm{C}_{8} \mathrm{H}_{12} \mathrm{ClNO}_{3}\right)$ (Sigma, Cat. no. 47862).

- Plasmid Maxi Kit (Qiagen, Cat. no. 12165).

- Sodium chloride (NaCl) (Sigma, Cat. no. S5886).

- Sodium hydroxide (NaOH) (Sigma, Cat. no. S8045)! CAUTION $\mathrm{NaOH}$ is corrosive. Handle it with care, and wear gloves and eye protection.

- Sodium molybdate dihydrate $\left(\mathrm{Na}_{2} \mathrm{MoO}_{4} \cdot 2 \mathrm{H}_{2} \mathrm{O}\right)$ (Sigma, Cat. no. M1003).

- Sodium phosphate monobasic dihydrate $\left(\mathrm{NaH}_{2} \mathrm{PO}_{4} \cdot 2 \mathrm{H}_{2} \mathrm{O}\right)$ (Sigma, Cat. no. 71505).

- Sucrose $\left(\mathrm{C}_{12} \mathrm{H}_{22} \mathrm{O}_{11}\right)$ (Sigma, Cat. no. S0389).

- Thiamine hydrochloride $\left(\mathrm{C}_{12} \mathrm{H}_{18} \mathrm{Cl}_{2} \mathrm{~N}_{4} \mathrm{OS}\right)$ (Sigma, Cat. no. T1270).

- Zinc sulphate heptahydrate $\left(\mathrm{ZnSO}_{4} \cdot 7 \mathrm{H}_{2} \mathrm{O}\right)$ (Sigma, Cat. no. Z0251).

\title{
Equipments
}

- $0.2-\mu \mathrm{m}$ filter $250 \mathrm{ml}$ (CORNING 431096).

- 440-nm diode laser (iFLEX 2000, Point Source).

- 60× oil-immersion objective lens (UPlanSApo $60 \times / 1.42$, Olympus).

- Centrifuge with a swinging bucket rotor (Eppendorf: 5804R and S-4-72).

- Confocal scanner (Yokogawa CSU22).

- Cooled charge-coupled device camera (Hamamatsu Photonics, EM-CCD C9100-02).

- Cover glass (Matsunami Glass, Small: $24 \times 32 \mathrm{~mm}$, 0.13-0.17 mm, C024321, Large: $24 \times 60 \mathrm{~mm}, 0.13-$ $0.17 \mathrm{~mm}, \mathrm{C} 024601)$.

- Dual-View image splitter (DualView: Optical Insights).

- FRET filter for dual-emission imaging (Omega Optical, CFP: $480 \pm 15 \mathrm{~nm}$ and Venus: $535 \pm 20 \mathrm{~nm}$ ).

- Inverted fluorescence microscope (Olympus IX-81).

- MetaMorph software (Universal Imaging).

- Microscope slide printed with highly water-repellent mark (Matsunami Glass, Cat. no. TF0215).

- Nylon mesh $(40 \mu \mathrm{m}$, Kyoshin Rikoh, Cat. no. PP40n).

- Leica SMD FLCS microscope.

\section{Recipies}

$1 \mathrm{M} \mathrm{CaCl}_{2}$

Cellulase solution

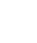

\section{$20 \mathrm{mg} / \mathrm{ml} 2,4-\mathrm{D}$}

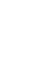


1 M FeEDTA

$40 \mathrm{mM} \mathrm{KNO}_{3}$

0.8 M Mannitol

$1 \mathrm{mM} \mathrm{MgSO}_{4}$

MMG solution

$2 \mathrm{mM} \mathrm{NaH}_{2} \mathrm{PO}_{4}$

$2.5 \mathrm{mM}\left(\mathrm{NH}_{4}\right)_{2} \mathrm{SO}_{4}$

PEG solution

R2 Macro $20 \times$ solution
Dissolve $375 \mathrm{mg}$ of $\mathrm{Na}_{2}$ EDTA and $275 \mathrm{mg}$ of $\mathrm{FeSO}_{4} \cdot 7 \mathrm{H}_{2} \mathrm{O}$ in $80 \mathrm{ml}$ of $\mathrm{ddH}_{2} \mathrm{O}$. Adjust the final volume to $100 \mathrm{ml}$. Store at $4{ }^{\circ} \mathrm{C}$.

Dissolve $0.4 \mathrm{~g}$ of $\mathrm{KNO}_{3}$ in $100 \mathrm{ml}$ of $\mathrm{ddH}_{2} \mathrm{O}$. Store at RT for up to 6 months.

Dissolve $14.6 \mathrm{~g}$ of $\mathrm{D}$-mannitol in $100 \mathrm{ml}$ of $\mathrm{ddH}_{2} \mathrm{O}$ and autoclave. Store at RT for up to 6 months.

Dissolve $25 \mathrm{mg}$ of $\mathrm{MgSO}_{4} \cdot 7 \mathrm{H}_{2} \mathrm{O}$ in $100 \mathrm{ml}$ of $\mathrm{dd}_{2} \mathrm{O}$ and autoclave. Store at RT for up to 6 months.

Dissolve $14.6 \mathrm{~g}$ of $\mathrm{D}$-mannitol, $0.6 \mathrm{~g}$ of $\mathrm{MgCl}_{2}$ and $170 \mathrm{mg}$ of $\mathrm{MES} \cdot \mathrm{H}_{2} \mathrm{O}$ in $160 \mathrm{ml}$ of $\mathrm{dd}_{2} \mathrm{O}$. Adjust the $\mathrm{pH}$ to 5.7 with $5 \mathrm{~N}$ $\mathrm{NaOH}$ and dilute to $200 \mathrm{ml}$ with $\mathrm{ddH}_{2} \mathrm{O}$. Autoclave and divide into 15-ml Falcon tubes. Store at RT for up to 1 month.

Dissolve $31 \mathrm{mg}$ of $\mathrm{NaH}_{2} \mathrm{PO}_{4} \cdot 2 \mathrm{H}_{2} \mathrm{O}$ in $100 \mathrm{ml}$ of $\mathrm{ddH}_{2} \mathrm{O}$. Store at RT for up to 6 months.

Dissolve $33 \mathrm{mg}$ of $\mathrm{MgSO}_{4} \cdot 7 \mathrm{H}_{2} \mathrm{O}$ in $100 \mathrm{ml}$ of $\mathrm{ddH}_{2} \mathrm{O}$. Store at RT for up to 6 months.

Prepare just before use. Dissolve $4.0 \mathrm{~g}$ of PEG4000 in $3 \mathrm{ml}$ of $\mathrm{ddH}_{2} \mathrm{O}$. Add $2.5 \mathrm{ml}$ of $0.8 \mathrm{M} \mathrm{D}$-mannitol and $1 \mathrm{ml}$ of $1 \mathrm{M} \mathrm{CaCl}_{2}$. Adjust volume to $10 \mathrm{ml}$ with $\mathrm{ddH}_{2} \mathrm{O}$. Dissolve and sterilize with a $0.2-\mu \mathrm{m}$ filter.

Dissolve $80.0 \mathrm{~g}$ of $\mathrm{KNO}_{3}$, $6.7 \mathrm{~g}$ of $\left(\mathrm{NH}_{4}\right)_{2} \mathrm{SO}_{4}, 5.0 \mathrm{~g}$ of $\mathrm{MgSO}_{4} \cdot 7 \mathrm{H}_{2} \mathrm{O}, 3.0 \mathrm{~g}$ of $\mathrm{CaCl}_{2} \cdot 2 \mathrm{H}_{2} \mathrm{O}$ and $5.5 \mathrm{~g}$ of $\mathrm{NaH}_{2} \mathrm{PO}_{4} \cdot 2 \mathrm{H}_{2} \mathrm{O}$ in $800 \mathrm{ml}$ of $\mathrm{ddH}_{2} \mathrm{O}$. Adjust the volume to $1 \mathrm{l}$ with $\mathrm{ddH}_{2} \mathrm{O}$. Store at $4{ }^{\circ} \mathrm{C}$.
R2 Micro $1000 \times$ solution Dissolve $160 \mathrm{mg}$ of $\mathrm{MnSO}_{4} \cdot 4 \mathrm{H}_{2} \mathrm{O}, 220 \mathrm{mg}$ of $\mathrm{ZnSO}_{4} \cdot 7 \mathrm{H}_{2} \mathrm{O}, 13 \mathrm{mg}$ of $\mathrm{CuSO}_{4} \cdot 5 \mathrm{H}_{2} \mathrm{O}, \quad 0.6 \mathrm{~g}$ of $\mathrm{H}_{3} \mathrm{BO}_{3}$ and $13 \mathrm{mg}$ of $\mathrm{Na}_{2} \mathrm{MoO}_{4} \cdot 2 \mathrm{H}_{2} \mathrm{O}$ in $800 \mathrm{ml}$ of $\mathrm{ddH}_{2} \mathrm{O}$. Adjust the volume to $1 \mathrm{l}$ with $\mathrm{ddd}_{2} \mathrm{O}$ and store at $4{ }^{\circ} \mathrm{C}$.

R2S

Dissolve $30.0 \mathrm{~g}$ of sucrose in $800 \mathrm{ml}$ of $\mathrm{ddH}_{2} \mathrm{O}$. Add $50 \mathrm{ml}$ of $20 \times$ R2 Macro, $2 \mathrm{ml}$ of FeEDTA, $1 \mathrm{ml}$ of $1000 \times$ R2 Micro, $1 \mathrm{ml}$ of MS Vitamin and $0.1 \mathrm{ml}$ of 2,4-D. Adjust the $\mathrm{pH}$ of the solution to 5.7 with $\mathrm{NaOH}$, and the volume to $1 \mathrm{l}$ with $\mathrm{ddH}_{2} \mathrm{O}$. Autoclave and store this medium at $4{ }^{\circ} \mathrm{C}$ for up to 1 month.

W5 solution

Dissolve $1.8 \mathrm{~g}$ of $\mathrm{NaCl}, 2.8 \mathrm{~g}$ of $\mathrm{CaCl}_{2} \cdot 2 \mathrm{H}_{2} \mathrm{O}, 70 \mathrm{mg}$ of $\mathrm{KCl}$ and $90 \mathrm{mg}$ of MES. $\mathrm{H}_{2} \mathrm{O}$ in $160 \mathrm{ml}$ of $\mathrm{ddH}_{2} \mathrm{O}$. Adjust the $\mathrm{pH}$ of the solution to 5.7 with $5 \mathrm{~N} \mathrm{NaOH}$, and the volume to $200 \mathrm{ml}$ with $\mathrm{ddH}_{2} \mathrm{O}$. Autoclave and store at RT for up to 1 month.

\section{Instruction}

This protocol describes a practical method for monitoring the activity of small GTPases in rice protoplasts using the intramolecular FRET biosensor. One of the most important factors for obtaining successful results is to develop a wide dynamic range of FRET biosensors. Since there are no standard protocols for making reliable Raichu constructs, we refrain from describing a detailed protocol on the development of FRET sensors in this protocol. Establishing reliable Raichu constructs requires a process of trial and error with many factors such as the choice of fluorescent proteins, the length of linkers and the combination of small GTPase and small GTPase-binding domain. For more information about sensor development, we refer readers to several excellent reviews of animal systems $[17,19,23,24]$. The protocol that follows consists of four steps: (1) cell culture and preparation of Oc cells; (2) isolation of protoplasts; (3) transfection of protoplasts with Raichu-OsRac1 plasmids; and (4) FRET imaging and data processing (Fig. 2). 


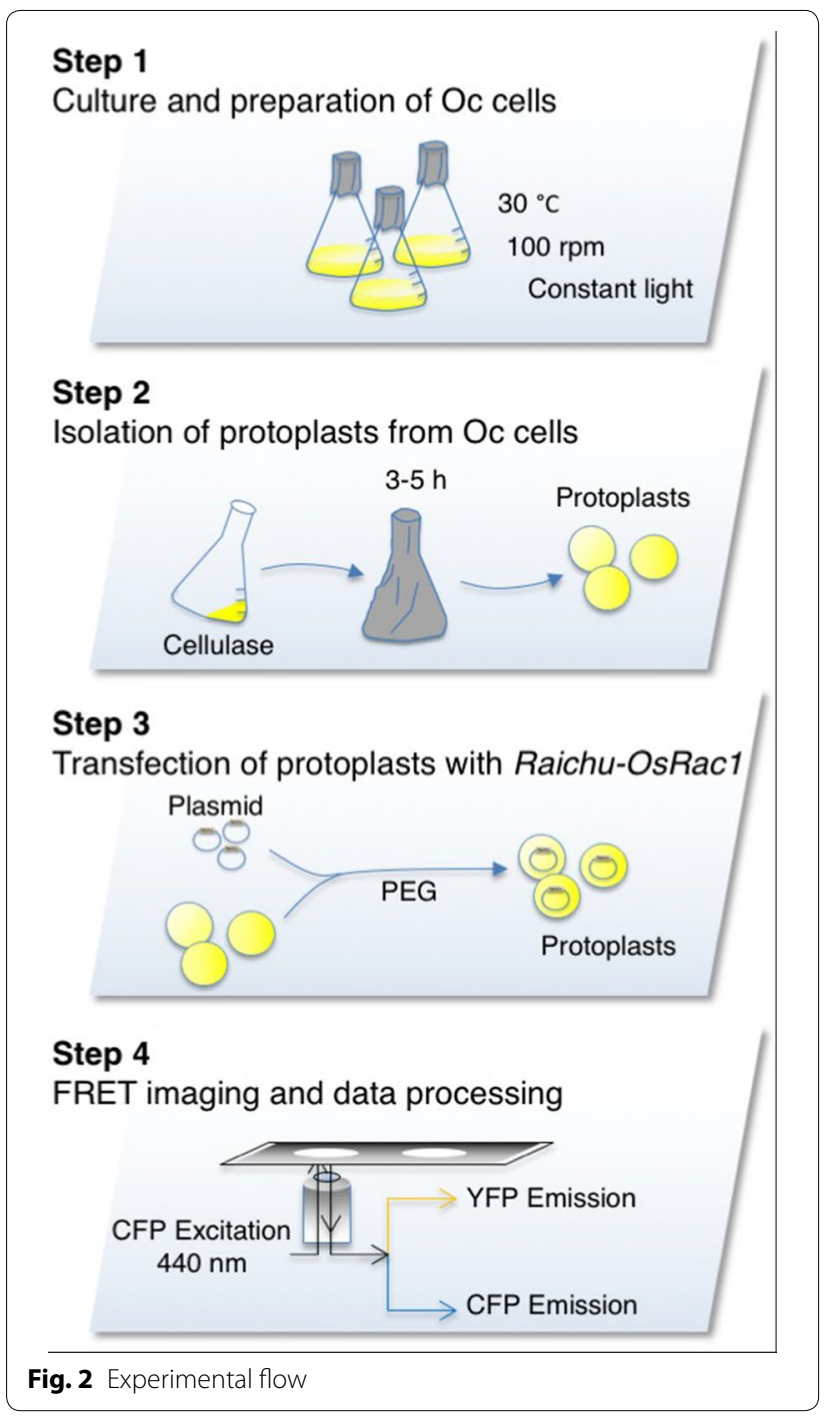

\section{Construction of Raichu-OsRac1}

We first tested the binding specificity of the CRIB domain of PAK for OsRac1 using a pull-down assay. PAK CRIB specifically bound to the constitutively active (G19V) form of OsRac1 (OsRac1 CA) and not to the dominant negative (T24N) form (OsRac1 DN), indicating that the interaction between PAK CRIB and OsRac1 occurs only when OsRac1 is activated [13]. The backbone of our Raichu-OsRac1 is essentially identical to that made by Itoh et al. [18], except that human Rac1 and the C-terminal polybasic region and CAAX box of human Ki-Ras are replaced by rice OsRac1 and the corresponding elements of OsRac1, respectively [13]. The choice of C-terminal polybasic region and post-translational modification site is also important, because subcellular localization of small GTPases is strongly influenced by these functions [25]. To determine whether the activation of OsRac1 increases FRET efficiency in vivo, we also prepared CA and DN forms of Raichu-OsRac1.

\section{Cell culture and preparation of Oc cells-time: 3 days}

We used Oryza sativa L. C5924 (Oc) cells to generate rice protoplasts for transfection assays of Raichu-OsRac1, because their transfection efficiency is much higher than that of protoplasts derived from other rice cultivars [26].

*All procedures should be done on a clean bench to avoid contamination

From a fully saturated $20-\mathrm{ml}$ suspension of Oc cells, we discard all medium as well as about half of the cells, and then add $20 \mathrm{ml}$ of fresh $\mathrm{R} 2 \mathrm{~S}$ medium in a 100-ml flask every week to maintain the cells. Cells are cultured at $30{ }^{\circ} \mathrm{C}$ with rotation at $100 \mathrm{rpm}$ under constant light. We change the flasks every month because debris accumulates on their inner surface.

1. Use fully saturated suspension cells cultured in fresh R2S medium for 3 days.

For transfection experiments, the medium of a fully saturated cell suspension is replaced with $20 \mathrm{ml}$ of fresh R2S medium and the cells are cultured for 3 days.

\section{Isolation of protoplasts from Oc cells-time: $\mathbf{6} \boldsymbol{h}$}

We developed a rice protoplast isolation and transfection method, according to Yoo et al., with minor modifications [27]. Cell walls of Oc cells are removed using cellulase and the protoplasts transfected with Raichu-OsRac1 vectors by a PEG method.

*All procedures should be done on a clean bench to avoid contamination (Fig. 3b).

1. Prepare a conical flask with a funnel and nylon mesh filter, and autoclave (Fig. 3c).

2. Irradiate a clean bench with ultraviolet light for 10-20 min.

3. Pre-warm cellulase solution at $30^{\circ} \mathrm{C}$ to thaw.

4. Completely remove R2S medium from a flask containing a 3-day culture (Fig. 3a); add $20 \mathrm{ml}$ of cellulase solution and cover the flask with aluminium foil.

5. Incubate the cells at $30^{\circ} \mathrm{C}$ with shaking at $50 \mathrm{rpm}$ for 3-5 h (Fig. 3d).

6. Add $20 \mathrm{ml}$ of W5 solution and filter the cells through a sheet of 40- $\mu$ m nylon mesh (Fig. 3e).

* All procedures should be conducted on ice.

To prevent the filters from clogging, we pipette the cells gently in 5-ml aliquots into the filter.

7. Transfer the filtered cells to a 50-ml Falcon tube. 

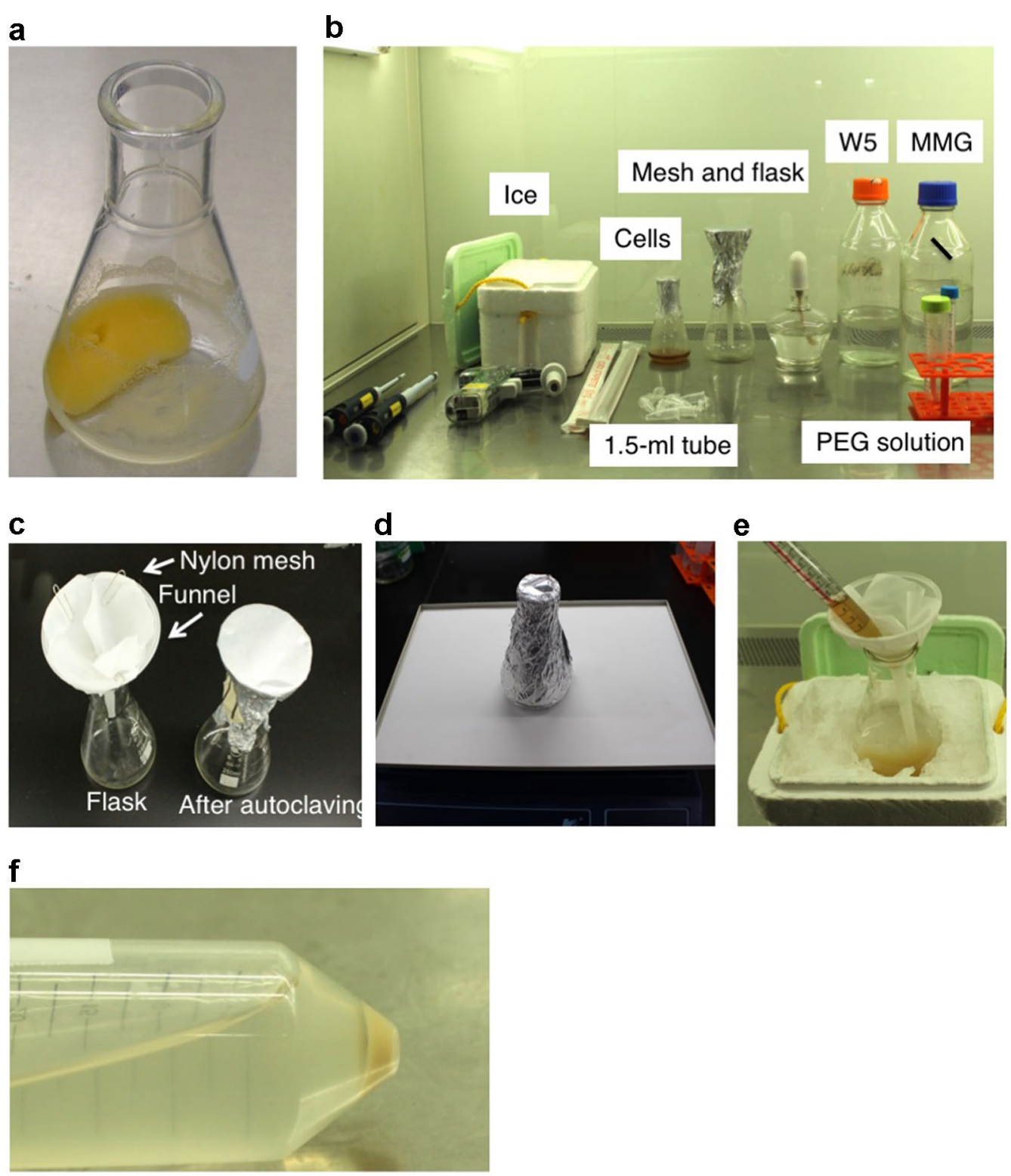

Fig. 3 Materials for transfection of rice protoplasts with Raichu-OsRac1. a Healthy Oc cells. b Materials required for transfection on a clean bench. c Preparation of a funnel with a nylon mesh filter. $\mathbf{d}$ Cellulase treatment on an orbital shaker. Incubate the cells with shaking at $50 \mathrm{rpm}$. e Filtration of cellulase-treated Oc cells. f, Precipitated cells after centrifugation with a swinging bucket rotor

8. Centrifuge the tube at $120 g$ for 4 min using a swinging bucket rotor.

Check whether sufficient cells are pelleted in the bottom of the tube (Fig. 3f).

9. Decant and discard the supernatant.

10. Add $20 \mathrm{ml}$ of $\mathrm{W} 5$ solution to the protoplast pellet and suspend it by gentle swirling.
11. Centrifuge at $120 \mathrm{~g}$ for 4 min using a swinging bucket rotor.

12. Discard the supernatant and add $2 \mathrm{ml}$ of W5 solution.

To avoid cell damage, resuspend the cells gently.

13. Keep the suspension on ice for $30 \mathrm{~min}$. 
14. Dilute $10 \mu \mathrm{l}$ of the protoplast suspension with $90 \mu \mathrm{l}$ of W5 solution to measure the density of protoplasts using a haemocytometer, and estimate the total number of protoplasts.

We count only intact, round cells. In general, we can obtain $2-8 \times 10^{6}$ cells from one flask. If your yield is very low, start again from the beginning.

15. Centrifuge at $120 \mathrm{~g}$ for 4 min using a swinging bucket rotor and discard the supernatant.

16. Resuspend the protoplasts at $2 \times 10^{6}$ cells $/ \mathrm{ml}$ with MMG.

"CRITICAL STEP For general experiments such as localization studies and analyses of gene expression, protoplasts can be kept at $4{ }^{\circ} \mathrm{C}$ for up to $24 \mathrm{~h}$, but freshly prepared protoplasts are essential for Raichu-OsRac1 experiments.

\section{Transfection of protoplasts with Raichu-OsRac1 plasmids}

In general, we are able to observe a 30-40\% transfection efficiency with control green fluorescent protein (GFP), and it is very important to keep this efficiency high to obtain reproducible and reliable results. Since it is easy to generate CA and DN mutants of small GTPases, we strongly recommend adding Raichu-OsRac1 $C A$ and $D N$ vectors as positive and negative controls to ensure a wide dynamic range of the Venus/CFP ratio in each experiment.

- All steps are carried out at $25^{\circ} \mathrm{C}$ (room temperature).

- Prepare plasmid DNA for transfection and fresh PEG solution.

The concentration of all of plasmids is adjusted to $2 \mu \mathrm{g} /$ $\mu \mathrm{l}$ with TE to minimize the volume of plasmid used in the transfection.

1. Add the required plasmids to a 1.5 - $\mathrm{ml}$ tube.

* CRITICAL STEP It is essential to optimize the amount and ratio of plasmids to suit your experimental design. The total amount of plasmid in each sample should not exceed $10 \mu \mathrm{l}$ or $10 \mu \mathrm{g}$, and should be the same for both test and control vectors.

2. Add $100 \mu$ l of protoplast suspension $\left(2 \times 10^{5}\right.$ cells $)$.

3. Add $110 \mu$ of PEG solution and mix gently by inverting the tube five times.

4. Incubate the transfection mixture for $20 \mathrm{~min}$ at room temperature.
5. Add $1 \mathrm{ml}$ of W5 solution to the tube and mix gently by inverting five times.

6. Centrifuge at $120 \mathrm{~g}$ for $10 \mathrm{~min}$ and discard the supernatant.

7. Add $100 \mu \mathrm{l}$ of W5 solution.

8. Suspend the protoplasts gently and place the tube in a light-resistant box on a slant.

We put the tube on a slant to prevent the fragile protoplasts from settling in the bottom of the tube, and we use a light-resistant box to prevent bleaching of the fluorescent proteins.

9. Incubate in the dark at $30{ }^{\circ} \mathrm{C}$ for $10-16 \mathrm{~h}$.

\section{FRET imaging and data processing}

Raichu-OsRac1 proteins begin to be expressed $8 \mathrm{~h}$ after transfection, and it usually takes until about $10 \mathrm{~h}$ after transfection to achieve sufficient expression of the biosensors. The optimal observation time is $10-16 \mathrm{~h}$ after transfection. FRET efficiencies may vary depending on the timing of observation, due to differences in the time required for maturation of donor and acceptor fluorescent proteins, and it is better to avoid observing cells beyond $16 \mathrm{~h}$ after transfection in our condition. The expression levels of Raichu-OsRac1 are different in individual cells and it is important to select cells displaying plasma membrane localization [28] and comparable levels of Raichu-OsRac1 [13].

To obtain time-lapse images of Raichu-OsRac1, we use an inverted microscope equipped with a Confocal Scanner Unit, a Dual-View image splitter and a CCD camera, which can simultaneously take CFP and Venus images (Fig. 6). The donor protein CFP is excited by a 440-nm diode laser. Average values for the fluorescence intensity of CFP and Venus in the region of interest are calculated after subtracting background fluorescence. The normalized FRET efficiency is then calculated according to Sorkin et al. [29].

1. Mount $10 \mu \mathrm{l}$ of the transfected rice protoplasts on a microscope slide.

We keep the 1.5-ml tube upright for $30 \mathrm{~min}$ to collect the transfected cells at the bottom of the tube, and then transfer $10 \mu \mathrm{l}$ of the cells to the recess of a microscope slide glass printed with a highly water-repellent mark and cover it with a cover glass using a nail varnish (Fig. 4a).

In time-lapse experiments using chitin, we prepare a smaller cover glass $(24 \times 32 \mathrm{~mm}$, thickness 0.12 $0.17 \mathrm{~mm}$ ) coated on its underside with $2 \%$ low-meltingtemperature agarose, according to Fig. $4 \mathrm{~b}$. We sandwich 


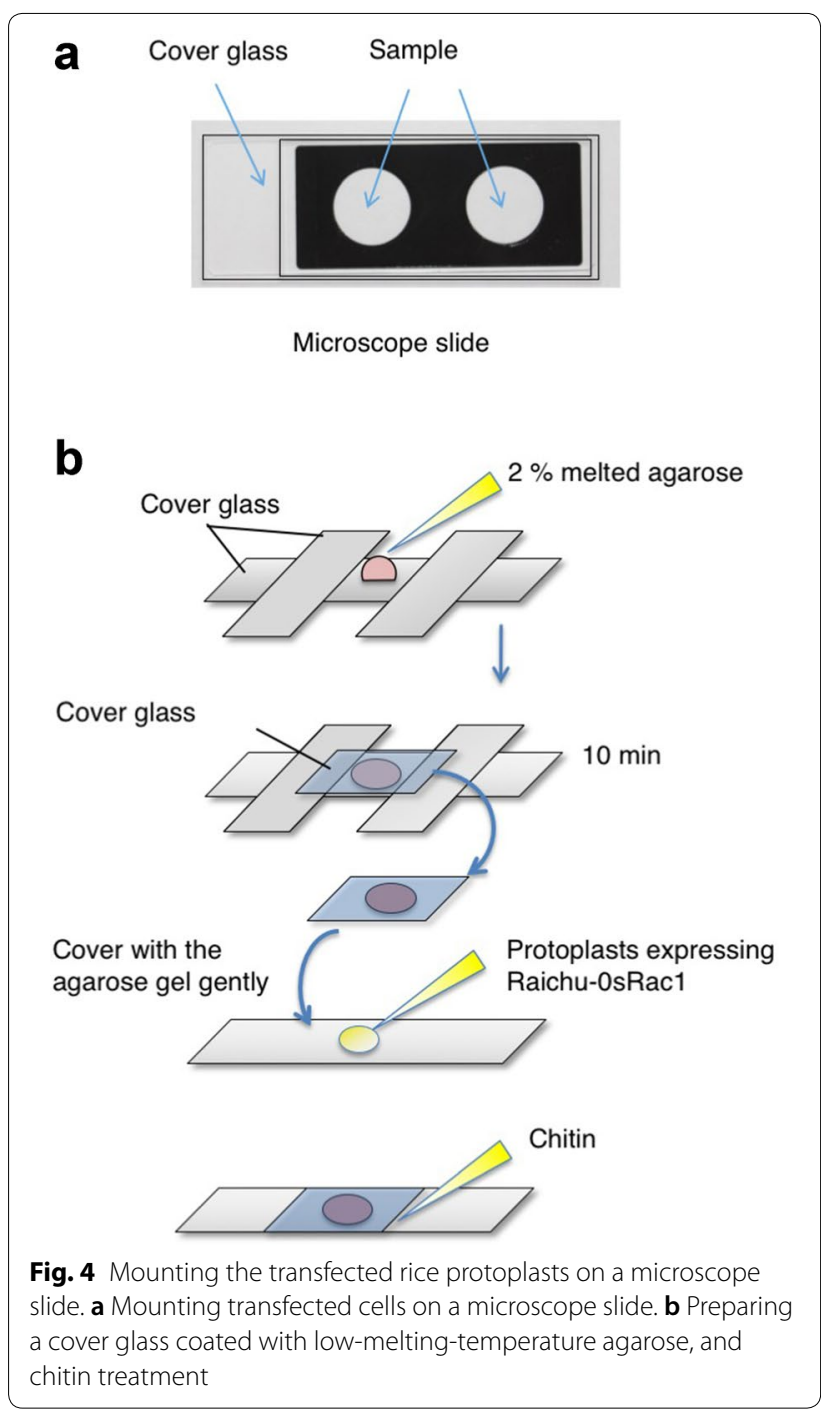

the melted agarose between the smaller and a larger $(24 \times 60 \mathrm{~mm}$, thickness $0.12-0.17 \mathrm{~mm})$ cover glass, using two large cover glasses as spacers, and allow it to set for $10 \mathrm{~min}$. We put $10 \mu \mathrm{l}$ of the transfected cells onto a new larger cover glass. To situate the cells, they are sandwiched between this larger cover glass and the smaller cover glass coated with low-melting-temperature agarose. Chitin is added via a small opening between the two cover glasses.

2. Open MetaMorph software and obtain images of Raichu-OsRac1.

For Fig. 5, the CFP and Venus filters were $480 \pm 15 \mathrm{~nm}$ and $535 \pm 20 \mathrm{~nm}$, respectively and the transformed cells were imaged using Leica SMD FLCS microscope. Raichu-OsRac1 was excited using a $440 \mathrm{~nm}$ solid-state laser. The CFP and Venus filters were $470 \pm 20 \mathrm{~nm}$ and $550 \pm 25 \mathrm{~nm}$, respectively. For Fig. 6, we use an inverted microscope (IX81: Olympus) equipped with a Confocal Scanner Unit (CSU22: Yokokawa), a Dual-View image splitter (DualView: Optical Insights), and a CCD camera (EM-CCD C9100-02: Hamamatsu). MetaMorph is used for capturing and analysing images. Using Multi Dimensional Acquisition Mode, donor protein CFP is excited by a $440-\mathrm{nm}$ diode laser, and we then take images for CFP $(480 \pm 15 \mathrm{~nm})$ and Venus $(535 \pm 20 \mathrm{~nm})$ at the same time. Our typical imaging conditions are sensitivity 50-150, and exposure time 1000-1500 ms. It is important to obtain images from healthy transfected cells that show appropriate localization of Raichu-OsRac1 in the plasma membrane [28], and also to carefully adjust sensitivity and exposure time to avoid saturation of the fluorescence images. Finally, we take photos of the protoplasts expressing Raichu-OsRac1.

\section{Subtract background and make ratio images.}

The emission spectra of CFP and Venus fluorescence are obtained simultaneously using a Dual-View image splitter. This slightly misaligns the position of CFP and Venus images, and the misalignment is corrected using the Align function of MetaMorph software. To precisely measure the fluorescence intensities of CFP and Venus, background fluorescence is subtracted from the images. The Region of Interest (ROI) is selected within appropriate areas that are devoid of fluorescent objects, and this background fluorescent intensity is subtracted from whole images.

4. Merge processed CFP and Venus images into a single image and measure the Venus/CFP ratio.

Using the background-subtracted CFP and Venus images, Venus images are divided by CFP images, thereby creating Venus/CFP ratio images. To quantitatively measure the Venus/CFP ratio images, we set ROIs over the cells of interest to measure the average intensity of Venus and CFP images using the Region Measurement function of MetaMorph software, and the obtained value is exported to a Microsoft Excel file. To visualize the activation level of OsRac1, the Venus/CFP ratio images are pesudo-coloured with the intensity-modulated display (IMD) mode, which divides the mean signal intensity of the Venus/CFP ratio into eight colours from red to blue (Figs. 5 and 6). In general, we can obtain sufficient dynamic ranges when we set the upper and lower limits of the IMD mode at about 0.5 higher and lower than the average ratio of Venus/CFP for Raichu-CA-OsRac1 and -DN-OsRac1, respectively. 

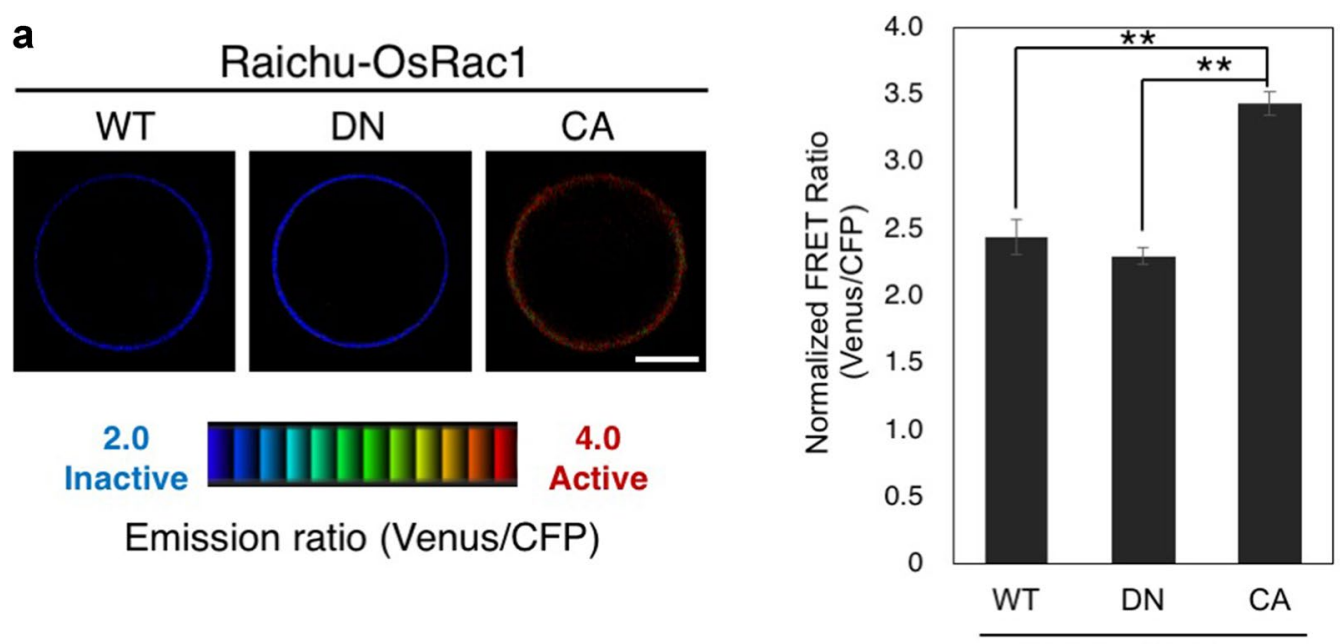

Raichu-OsRac1

b

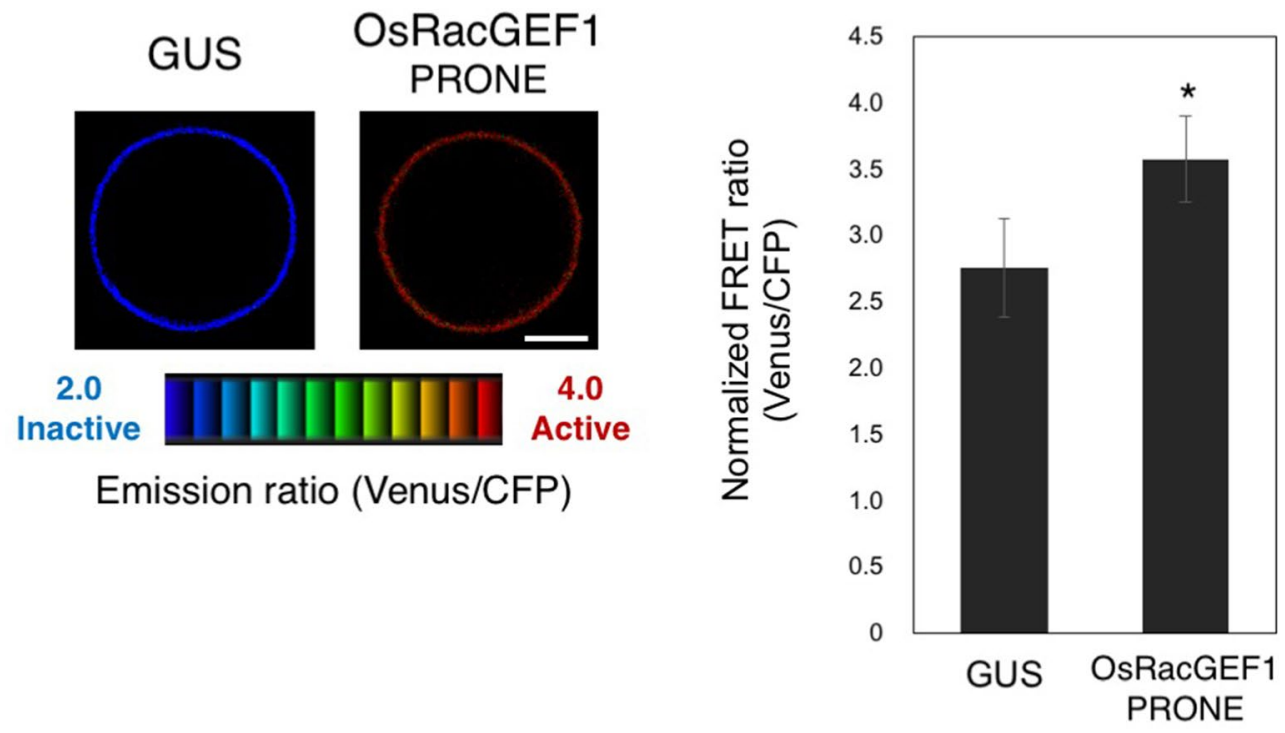

Fig. 5 Validating the Raichu-OsRac1 FRET sensor. a, b Emission ratio images of rice protoplasts expressing Raichu-OsRac1 mutants. Rice protoplasts were transfected with constructs expressing Raichu-OsRac1 WT, mutants and the PRONE domain of OsRacGEF1. Double asterisks indicate significant differences from the data for WT-OsRac1 or control GUS enzyme $(P<0.01)$. Error bars indicate SE $(n>30)$

\section{Process data.}

For statistical analyses, corrected FRET (cFRET) followed by normalized FRET (nFRET) are calculated, according to Sorkin et al., [29] with minor modifications. Fluorescence in the Venus channel consists of FRET and non-FRET fluorescence derived from the cross-over of Venus and CFP fluorescence through the FRET filters. Cross-over between Venus and CFP fluorescence divides into two factors: CFP emission detected in the Venus channel (xCFP) and Venus emission induced by CFP excitation (yVenus). cFRET is calculated as follows: $c F R E T=$ total Venus $-x C F P$ $-y$ Venus. The extent of cross-over ( $x$ and $y$ ) is a characteristic value in each optical system and must be obtained in advance using cells expressing either Venus or CFP and the following formulae:

Cells expressing CFP

$\mathrm{x}=$ Fluorescence in Venus channel when CFP is activated by CFP excitation/CFP emission induced by CFP excitation 

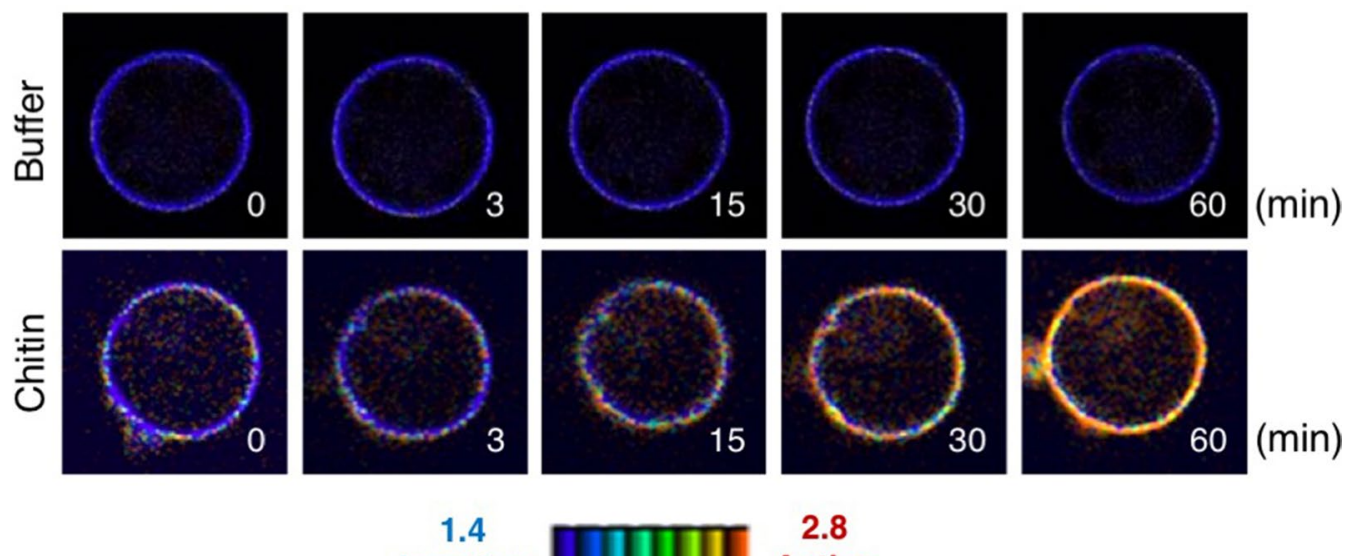

Inactive

2.8

Active

Emission ratio (YFP/CFP)

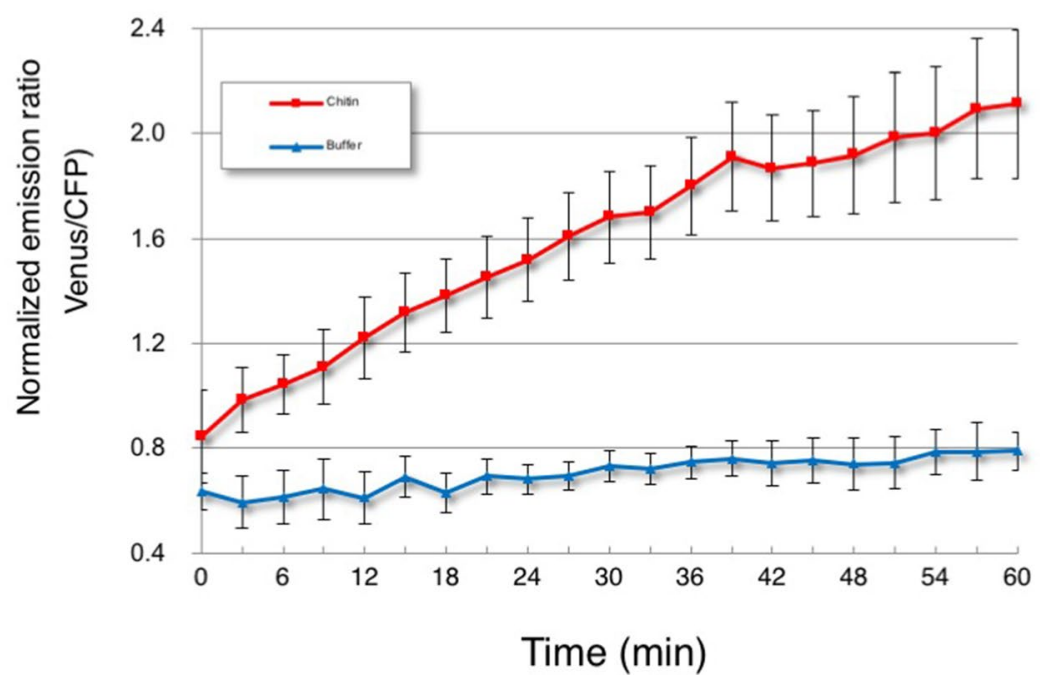

Fig. 6 Monitoring OsRac1 activation after treatment of rice protoplasts with the MAMP chitin. Time-lapse imaging of rice protoplasts expressing Raichu-OsRac1-WT after chitin treatment. Red line, $0.5 \mathrm{\mu g} / \mathrm{ml}$ chitin treatment; blue line, W5 buffer treatment. The FRET images are shown in IMD mode, which associates colour hue with emission ratio values and the intensity of each hue with the brightness of the source image. Bars: $5 \mu$ m. This figure is adapted from Akamatsu et al. [22] with permission from Cell Press

Cells expressing Venus

$$
\begin{aligned}
\mathrm{y}= & \text { Fluorescence in Venus channel when Venus } \\
& \text { is activated by CFP excitation/Venus emission } \\
& \text { induced by Venus excitation }
\end{aligned}
$$

In our optical system, $\mathrm{x}$ and $\mathrm{y}$ are about 0.77 and 0.02 , respectively, which are conservative values that we can continue to use until we change the optical system. The $y$ value is much smaller than the $x$ value, and we do not take the $y$ value into consideration. As shown in the formula above, the cFRET value is affected by the expression level of CFP and Venus; thus, cFRET is divided by CFP as follows:

$\mathrm{nFRET}=\mathrm{cFRET} / \mathrm{CFP}$ emission induced by CFP excitation.

To examine whether the activation of OsRac1 increased FRET efficiency in living cells, we transfected rice protoplasts with Raichu-OsRac1 WT, DN and CA. OsRac1 has been shown previously to localize to the plasma membrane [28]. Consistent with this, Raichu-OsRac1 was localized mainly at the plasma membrane. The ratio of Venus/CFP fluorescence in protoplasts expressing Raichu-CA-OsRac1 was higher than those in protoplasts 
expressing either Raichu-WT-OsRac1 or Raichu-DNOsRac1 (Fig. 5a), indicating that the interaction between CRIB and OsRac1 occurs only when OsRac1 is activated. These results demonstrate that the ratios of Venus/CFP fluorescence for Raichu-OsRac1 reflect the activation state of OsRac1 in rice protoplasts.

We have previously found that a PRONE-type GEF, OsRacGEF1, displays GEF activity towards OsRac1 in vitro and plays an important role in the activation of OsRac1 in chitin-induced immune responses [22]. To extend that observation, we next tried to monitor the activation of OsRac1 by OsRacGEF1 in living cells. In control GUS-transfected cells, the ratio of Venus/ CFP fluorescence of Raichu-OsRac1 was low, but when we expressed the PRONE domain of OsRac1GEF1 (OsRacGEF1 PRONE), the ratio increased (Fig. 5b), showing that OsRacGEF1 PRONE indeed activates OsRac1 in rice protoplasts.

To elucidate the spatiotemporal regulation of OsRac1 activation in MAMP-triggered immunity, we treated the rice protoplasts with chitin, which is a component of pathogenic and non-pathogenic fungi and is one of the best-studied MAMPs. Chitin markedly and rapidly induced OsRac1 activation in the rice protoplasts; in contrast, the OsRac1 activation level was negligible in cells treated with buffer (Fig. 6). Together, these results show that OsRac1 is rapidly activated at the plasma membrane of rice protoplasts after chitin elicitor treatment.

\section{Troubleshooting (also see Table 1)}

The condition of the Oc cells is the most important factor to obtain successful results, and the cells have to be treated carefully. Cells that are in good condition are bright yellow, and a white colour indicates that they are not in good condition (Fig. 3a). The incubation time strongly affects transfection efficiency and yield of cells. In Oc cells, a 3-h treatment is sufficient to obtain protoplasts, but if you cannot obtain sufficient protoplasts, you can extend the incubation time to $5 \mathrm{~h}$. If you are using different rice cultivars, it may be desirable to optimize the incubation time for your experimental conditions in advance.

Plasmid purity affects the transfection efficiency and we highly recommend the use of animal transfection grade plasmid purification kits or $\mathrm{CsCl}$ gradient purification.

\section{Conclusions}

In this study, we established a FRET sensor to monitor activation of small GTPase OsRac1. Moreover, using the same protocol, we have previously monitored the interaction between OsRac1 and its effector protein OsRbohB by FRET sensor and revealed that cytosolic $\mathrm{Ca}^{2+}$ concentration regulates the OsRac1-OsRbohB interaction in a dynamic manner [25]. Recently, Xie et al. employed the modified version Raichu-OsRac1 and bimolecular fluorescence complementation (BiFC)-based FRET to demonstrate the ternary repressor complexes that modulate histone deacetylation and/or methylation [30]. Since the principle of the intramolecular FRET biosensor appears to have universal applications for all of the small GTPases, we believe this Raichu system will become used in diverse research areas for understanding the spatiotemporal regulation of plant small GTPases and protein-protein interactions and this protocol can be adapted for for other FRET in various plants.

It was important for us to address the issue of whether OsRac1 is activated following pathogen recognition in planta. We therefore tried to make transgenic rice plants expressing Raichu-OsRac1. Unfortunately, we have not yet been able to observe Raichu-OsRac1 fluorescence in planta. This may be due to homology-dependent silencing of YFP and CFP expression, a problem that has been encountered by other researchers endeavouring to develop stably expressed FRET biosensors in planta [31]. Further work is necessary to resolve this issue.

Table 1 Troubleshooting

\begin{tabular}{|c|c|c|}
\hline Problem & Possible reason & Solution \\
\hline \multirow[t]{4}{*}{$\begin{array}{l}\text { Low protoplast yield and low trans- } \\
\text { fection efficiency }\end{array}$} & Condition of suspension cells & $\begin{array}{l}\text { Suspension cell condition is the most important factor for obtaining suc- } \\
\text { cessful results. If you have problems with a transfection, prepare new } \\
\text { suspension cells from your stock or rice seeds }\end{array}$ \\
\hline & Insufficient cellulase digestion & $\begin{array}{l}\text { Optimize the period of cellulase treatment or prepare fresh cellulase solu- } \\
\text { tion }\end{array}$ \\
\hline & Problem with transfection reagents & $\begin{array}{l}\text { Prepare new transfection reagents. PEG solution can not be stored, and you } \\
\text { should prepare fresh PEG for each experiment }\end{array}$ \\
\hline & Low DNA quality & Use an animal transfection grade of DNA purification kit \\
\hline Decay of FRET signal during imaging & Photobleaching by the excitation & Minimize exposure time and duration of laser excitation \\
\hline
\end{tabular}




\section{Authors' contributions}

HLW, AA, YK, and KS designed the study; HLW, AA, QW, MH, TM, JO, KK, QW and $Y K$ performed experiments and analyzed data; YK, TK, and KK wrote the manuscript; MH, NI, TK, SN, LT, and KS gave technical support and conceptual advice. All authors read and approved the final manuscript.

\begin{abstract}
Author details
${ }^{1}$ Laboratory of Plant Molecular Genetics, Graduate School of Biological Sciences, Nara Institute of Science and Technology, Nara 630-0192, Japan. ${ }^{2}$ Present Address: Department of Biological Science, University Tunku Abdul Rahman, Jalan Universiti, Bandar Barat, 31900 Kampar, Perak, Malaysia. ${ }^{3}$ Present Address: Department of Bioscience, Kwansei Gakuin University, 2-1 Gakuen, Sanda 669-1337, Japan. ${ }^{4}$ Present Address: Signal Transduction and Immunity Group, CAS Center for Excellence in Molecular Plant Sciences, Shanghai Center for Plant Stress Biology, Chinese Academy of Sciences, No. 3888 Chenhua Road, Shanghai 201602, China. ${ }^{5}$ University of Chinese Academy of Sciences, Beijing 100049, China. ${ }^{6}$ College of Life, Environment, and Advanced, Osaka Prefecture University Sciences, Sakai, Osaka 599-8531, Japan. ${ }^{7}$ Present Address: Department of Advanced Bioscience, Kindai University, 3327-204 Nakamachi, Nara 631-8505, Japan. ${ }^{8}$ College of Pharmaceutical Sciences, Ritsumeikan University, Kusatsu, Japan. ${ }^{9}$ Core Facility of Cell Biology, Shanghai Center for Plant Stress Biology, No. 3888 Chenhua Road, Shanghai 201602, China. ${ }^{10}$ Present Address: FAFU-UCR Joint Center and Fujian Provincial Key Laboratory of Haixia Applied Plant Systems Biology, Haixia Institute of Science and Technology, Fujian Agriculture and Forestry University, Fuzhou, Fujian, China. ${ }^{11}$ Kihara Institute for Biological Research, Yokohama City University, 641-12 Maioka, Totsuka, Yokohama, Kanagawa 244-0813, Japan.
\end{abstract}

\section{Acknowledgements}

We thank Dr. Michiyuki Matsuda for providing the Raichu-Rac1 vector. We appreciate Ms. Tomoko Aoi for excellent technical assistance. We also thank the members of the Laboratory of Plant Molecular Genetics at NAIST and the Laboratory of Signal Transduction and Immunity at PSC for invaluable support and discussions. Figure 6 is reproduced from Akamatsu et al., Cell Host Microbe 2013, 13(4):465-476 by copyright permission of the Cell Press. Dedicated to Ko Shimamoto, who passed away on September 28, 2013.

\section{Competing interests}

The authors declare that they have no competing interests.

\section{Availability of data and materials}

The datasets used and/or analyzed during the current study are available from the corresponding author on reasonable request.

\section{Consent for publication}

Not applicable.

\section{Ethics approval and consent to participate}

Not applicable.

\section{Funding}

Yoji Kawano was supported by National Natural Science Foundation in China (31572073 and 31772246), Chinese Academy of Sciences Hundred Talents Program (173176001000162114), Chinese Academy of Sciences, Shanghai Institutes for Biological Sciences, Shanghai Center for Plant Stress Biology, CAS Center of Excellence for Molecular Plant Sciences, JSPS KAKENHI, and the Takeda Science Foundation. Akira Akamatsu was supported by a fellowship from JSPS.

\section{Publisher's Note}

Springer Nature remains neutral with regard to jurisdictional claims in published maps and institutional affiliations.

Received: 20 January 2018 Accepted: 29 June 2018

Published online: 07 July 2018

\section{References}

1. Tsien RY, Miyawaki A. Seeing the machinery of live cells. Science. 1998:280(5371):1954-5.

2. Jares-Erijman EA, Jovin TM. FRET imaging. Nat Biotechnol. 2003:21(11):1387-95.

3. Aoki K, Matsuda M. Visualization of small GTPase activity with fluorescence resonance energy transfer-based biosensors. Nat Protoc. 2009;4(11):1623-31.

4. Miyawaki A, Llopis J, Heim R, McCaffery JM, Adams JA, Ikura M, Tsien RY Fluorescent indicators for $\mathrm{Ca}^{2+}$ based on green fluorescent proteins and calmodulin. Nature. 1997;388(6645):882-7.

5. Mochizuki N, Yamashita S, Kurokawa K, Ohba Y, Nagai T, Miyawaki A, Matsuda M. Spatio-temporal images of growth-factor-induced activation of Ras and Rap1. Nature. 2001;411(6841):1065-8.

6. Sipieter F, Vandame P, Spriet C, Leray A, Vincent P, Trinel D, Bodart JF, Riquet FB, Heliot L. From FRET imaging to practical methodology for kinase activity sensing in living cells. Prog Mol Biol Transl Sci. 2013;113:145-216.

7. Craddock C, Lavagi I, Yang Z. New insights into Rho signaling from plant ROP/Rac GTPases. Trends Cell Biol. 2012;22(9):492-501.

8. Yalovsky S. Protein lipid modifications and the regulation of ROP GTPase function. J Exp Bot. 2015;66(6):1617-24.

9. Kawano Y, Kaneko-Kawano T, Shimamoto K. Rho family GTPase-dependent immunity in plants and animals. Front Plant Sci. 2014;5:522.

10. Kawano Y, Shimamoto K. Early signaling network in rice PRR- and R-mediated immunity. Curr Opin Plant Biol. 2013;16:496-504.

11. Sander EE, van Delft S, ten Klooster JP, Reid T, van der Kammen RA, Michiels F, Collard JG. Matrix-dependent Tiam1/Rac signaling in epithelial cells promotes either cell-cell adhesion or cell migration and is regulated by phosphatidylinositol 3-kinase. J Cell Biol. 1998;143(5):1385-98.

12. Tao LZ, Cheung AY, Wu HM. Plant Rac-like GTPases are activated by auxin and mediate auxin-responsive gene expression. Plant Cell. 2002;14(11):2745-60

13. Kawano Y, Akamatsu A, Hayashi K, Housen Y, Okuda J, Yao A, Nakashima A Takahashi H, Yoshida H, Wong HL, et al. Activation of a Rac GTPase by the NLR family disease resistance protein Pit plays a critical role in rice innate immunity. Cell Host Microbe. 2010;7(5):362-75.

14. Xu T, Wen M, Nagawa S, Fu Y, Chen JG, Wu MJ, Perrot-Rechenmann C, Friml J, Jones AM, Yang Z. Cell surface- and rho GTPase-based auxin signaling controls cellular interdigitation in Arabidopsis. Cell. 2010;143(1):99-110

15. Kraynov VS, Chamberlain C, Bokoch GM, Schwartz MA, Slabaugh S, Hahn KM. Localized Rac activation dynamics visualized in living cells. Science. 2000;290(5490):333-7.

16. Fu Y, Gu Y, Zheng Z, Wasteneys G, Yang Z. Arabidopsis interdigitating cell growth requires two antagonistic pathways with opposing action on cell morphogenesis. Cell. 2005;120(5):687-700.

17. Miyawaki A. Visualization of the spatial and temporal dynamics of intracellular signaling. Dev Cell. 2003;4(3):295-305.

18. Itoh RE, Kurokawa K, Ohba Y, Yoshizaki H, Mochizuki N, Matsuda M. Activation of rac and cdc42 video imaged by fluorescent resonance energy transfer-based single-molecule probes in the membrane of living cells. Mol Cell Biol. 2002:22(18):6582-91.

19. Kiyokawa E, Aoki K, Nakamura T, Matsuda M. Spatiotemporal regulation of small GTPases as revealed by probes based on the principle of Forster Resonance Energy Transfer (FRET): implications for signaling and pharmacology. Annu Rev Pharmacol Toxicol. 2011;51:337-58.

20. Kawano Y, Chen L, Shimamoto K. The function of Rac small GTPase and associated proteins in rice innate immunity. Rice. 2010;3:112-21.

21. Kawano Y, Fujiwara T, Yao A, Housen Y, Hayashi K, Shimamoto K. Palmitoylation-dependent membrane localization of the rice resistance protein pit is critical for the activation of the small GTPase OsRac1. J Biol Chem. 2014;289(27):19079-88.

22. Akamatsu A, Wong H, Fujiwara M, Okuda J, Nishide K, Uno K, Imai K, Umemura K, Kawasaki T, Kawano Y, et al. An OsCEBiP/OsCERK1-OsRacGEF1OsRac1 module is an essential component of chitin-induced rice immunity. Cell Host Microbe. 2013;13(4):465-76.

23. Nakamura T, Aoki K, Matsuda M. Monitoring spatio-temporal regulation of Ras and Rho GTPase with GFP-based FRET probes. Methods. 2005;37(2):146-53. 
24. Komatsu N, Aoki K, Yamada M, Yukinaga H, Fujita Y, Kamioka Y, Matsuda M. Development of an optimized backbone of FRET biosensors for kinases and GTPases. Mol Biol Cell. 2011;22(23):4647-56.

25. Wong HL, Pinontoan R, Hayashi K, Tabata R, Yaeno T, Hasegawa K, Kojima C, Yoshioka H, Iba K, Kawasaki T, et al. Regulation of rice NADPH oxidase by binding of Rac GTPase to its N-terminal extension. Plant Cell. 2007;19(12):4022-34.

26. Baba A, Hasezawa S, Syono K. Cultivation of rice protoplasts and their transformation mediated by Agrobacterium spheroplasts. Plant Cell Physiol. 1986;27(3):463-71.

27. Yoo SD, Cho YH, Sheen J. Arabidopsis mesophyll protoplasts: a versatile cell system for transient gene expression analysis. Nat Protoc. 2007;2(7):1565-72.

28. Ono E, Wong HL, Kawasaki T, Hasegawa M, Kodama O, Shimamoto K. Essential role of the small GTPase Rac in disease resistance of rice. Proc Natl Acad Sci USA. 2001;98(2):759-64.
29. Sorkin A, McClure M, Huang F, Carter R. Interaction of EGF receptor and grb2 in living cells visualized by fluorescence resonance energy transfer (FRET) microscopy. Curr Biol. 2000;10(21):1395-8.

30. Xie Y, Zhang Y, Han J, Luo J, Li G, Huang J, Wu H, Tian Q, Zhu Q, Chen $Y$, et al. The intronic cis element SE1 recruits trans-acting repressor complexes to repress the expression of ELONGATED UPPERMOST INTERNODE1 in rice. Mol Plant. 2018;11(5):720-35.

31. Deuschle K, Chaudhuri B, Okumoto S, Lager I, Lalonde S, Frommer WB. Rapid metabolism of glucose detected with FRET glucose nanosensors in epidermal cells and intact roots of Arabidopsis RNA-silencing mutants. Plant Cell. 2006;18(9):2314-25.
Ready to submit your research? Choose BMC and benefit from:

- fast, convenient online submission

- thorough peer review by experienced researchers in your field

- rapid publication on acceptance

- support for research data, including large and complex data types

- gold Open Access which fosters wider collaboration and increased citations

- maximum visibility for your research: over $100 \mathrm{M}$ website views per year

At BMC, research is always in progress.

Learn more biomedcentral.com/submissions 